\title{
Effect of diazoxide or glucagon on hepatic glucose production rate during extreme neonatal hypoglycaemia
}

\author{
A MEHTA, R WOOTTON, K N CHENG, P PENFOLD, D HALLIDAY, AND T E STACEY \\ Section of Perinatal and Child Health, Division of Comparative Medicine, and Nutrition Research Group, \\ Clinical Research Centre, Harrow, Middlesex
}

SUMmARY The relation between hepatic glucose production rate (HGPR) and plasma concentrations of insulin and glucagon was investigated in four term neonates who had severe hypoglycaemia. The hepatic glucose production rate was less than $20 \%$ of normal for fasting term neonates in all four babies and yet insulin concentrations were never $>12 \mu \mathrm{U} / \mathrm{ml}$; two babies had very low glucagon concentrations $(<60 \mathrm{ng} / \mathrm{l})$. Two further neonates with similar histories also had plasma glucagon concentrations that were also extremely low $(<20 \mathrm{ng} / \mathrm{l})$. A single intravenous bolus of glucagon caused a rapid rise in hepatic glucose production rate towards the normal range, which was sustained for many hours after the bolus had been given. Diazoxide given to one baby suppressed previously 'normal' insulin concentrations still further $(4 \cdot 2$ to $<1.6$ $\mu \mathrm{U} / \mathrm{ml}$ ) and thereby restored the hepatic glucose production rate to normal. In view of the normal plasma insulin concentrations at a time when the hepatic glucose production rate was reduced, we feel that the absolute concentration of insulin may be less important than the insulin/glucagon molar ratio in the control of glucose homeostasis in this group of infants. The changing of this ratio by means of boluses of glucagon may be useful in preventing rebound hypoglycaemia, which so often occurs when dextrose infusions are reduced either accidentally or in an attempt to restart oral feeds.

Although hypoglycaemia is a well recognised complication in babies who are preterm or small for gestational age, it can also occur in term neonates who are otherwise well. In these babies it is often a severe problem in terms of clinical management. Many of them have no obvious disorder such as an inherited metabolic disease or maternal diabetes mellitus to explain their low plasma glucose concentration and yet they often require more than 55 $\mu \mathrm{mol} / \mathrm{kg} / \mathrm{min}$ of intravenous dextrose to prevent hypoglycaemia (normal range $27-44 \mu \mathrm{mol} / \mathrm{kg} / \mathrm{min}$ ). This extremely high rate of dextrose infusion sets this group of infants apart from others with hypoglycaemia because of their inability to maintain euglycaemia during even the shortest of fasts or during 'normal' rates of glucose infusion.

They may still have an extremely labile plasma glucose concentration, despite being given dextrose intravenously, and often have convulsions if the rate of infusion falls suddenly, which may occur when the drip tissues. It is often assumed that the hypoglycaemia is due to 'hyperinsulinism', ${ }^{1}$ but the exact relation between plasma insulin concentration and rate of glucose production and release from the liver remains unclear.

This relation has been studied in six infants (table 1). We have made serial measurements of the plasma concentration of insulin and glucagon in five infants, and in three we were able to measure the change in hepatic glucose production rate in response to treatment with diazoxide or glucagon.

\section{Patients}

Case 1. A girl, the second of HLA identical twins, was born at term with birth weight $2640 \mathrm{~g}$ by elective lower segment caesarean section to unrelated Jewish parents. She required resuscitation at birth (Apgar scores 3 and 7 at one and five minutes, respectively) and by 10 hours had a plasma glucose concentration 
Table 1 Clinical data on the study group

\begin{tabular}{|c|c|c|c|c|c|c|c|}
\hline \multirow{2}{*}{$\begin{array}{l}\text { Case } \\
\text { No }\end{array}$} & \multirow{2}{*}{$\begin{array}{l}\text { Birth } \\
\text { weight } \\
\text { (g) }\end{array}$} & \multicolumn{2}{|c|}{ At diagnosis } & \multirow{2}{*}{$\begin{array}{l}\text { Highest } \\
\text { observed } \\
\text { insulin } \\
\text { concentration }\end{array}$} & \multirow{2}{*}{$\begin{array}{l}\text { Glucose } \\
\text { concentration } \\
\text { at this } \\
\text { time }\end{array}$} & \multirow{2}{*}{$\begin{array}{l}\text { Pretreatment } \\
\text { glucagon } \\
\text { concentration } \\
(\text { ng/l) }\end{array}$} & \multirow[t]{2}{*}{ Treatment } \\
\hline & & Age (h) & $\begin{array}{l}\text { Glucose } \\
\text { concentration } \\
\text { (mmol/l) }\end{array}$ & & & & \\
\hline 1 & 2640 & 10 & 0 & $11 \cdot 8$ & $2 \cdot 4$ & - & Diazoxide \\
\hline 2 & 3000 & 50 & $0 \cdot 6$ & 10 & 0.6 & $<60$ & Glucagon \\
\hline 3 & $2600)$ & 12 & 1 & 10 & 1 & - & Glucagon \\
\hline 5 & 2100 & 12 & 0 & 4 & 0 & $<20$ & Glucagon \\
\hline 6 & 3900 & 1 & $0 \cdot 1$ & 9 & $2 \cdot 6$ & $<20$ & Glucagon \\
\hline
\end{tabular}

*This baby had received boluses of $20 \%$ dextrose before the sample was taken.

of $1 \mathrm{mmol} / \mathrm{l}$, which failed to rise above $3 \mathrm{mmol} / \mathrm{l}$ over the next six days, even though she was given up to $83 \mu \mathrm{mol} / \mathrm{kg} / \mathrm{min}$ of intravenous dextrose. Glucose turnover measurements were made on day 6 and again after five days of treatment with oral diazoxide (10 mg three times a day). The first twin did not become hypoglycaemic at any stage.

Case 2. An Asian boy was born at term with birth weight $3000 \mathrm{~g}$ by elective lower segment caesarean section for breech presentation after an unremarkable pregnancy. Severe maternal bleeding occurred at delivery and he required resuscitation (Apgar scores 5 and 9 at one and five minutes, respectively). He fed poorly for the first two days and had a grand mal convulsion at 50 hours, at which time his plasma glucose concentration was $0.6 \mathrm{mmol} / \mathrm{l}$. This failed to rise above $2 \mathrm{mmol} / \mathrm{l}$, even though he was given up to $83 \mu \mathrm{mol} / \mathrm{kg} / \mathrm{min}$ of intravenous dextrose for the next 24 hours. There was no evidence of sepsis and he was treated with phenobarbitone for the convulsions. Glucose turnover studies were performed during treatment with $200 \mu \mathrm{g} / \mathrm{kg}$ of intravenous glucagon on the third day of life.

Case 3. A boy was born at term with birth weight $2560 \mathrm{~g}$ by vertex vaginal delivery after induction of labour because of maternal hypertension and proteinuria. He became tachypnoeic and hypothermic at 12 hours, with a plasma glucose concentration of 1 $\mathrm{mmol} / \mathrm{l}$, which failed to rise above $2 \mathrm{mmol} / \mathrm{l}$ over the next 48 hours, despite administration of $55 \mu \mathrm{mol} / \mathrm{kg} /$ min of intravenous dextrose. After this his plasma glucose concentration fell to $1.1 \mathrm{mmol} / \mathrm{l}$ and he was given a bolus of $0.3 \mu \mathrm{g} / \mathrm{kg}$ of glucagon intravenously after which the plasma glucose concentration rose to $6 \mathrm{mmol} / \mathrm{l}$ within 30 minutes and remained above 2.5 $\mathrm{mmol} / \mathrm{l}$ for the next nine hours. A second bolus of glucagon was necessary when the plasma glucose concentration fell once again, and a glucose turnover study was carried out during this period.
Case 4. A girl born by vertex vaginal delivery at 42 weeks' gestation with a birth weight of $3220 \mathrm{~g}$ presented with convulsions secondary to hypoglycaemia at 46 hours. Her plasma glucose concentration rose to $2 \mathrm{mmol} / \mathrm{l}$ after administration of $38 \cdot 8$ $\mu \mathrm{mol} / \mathrm{kg} / \mathrm{min}$ of intravenous dextrose but was noted to be extremely labile. In addition, she required repeated $2 \mathrm{ml}$ boluses of $20 \%$ intravenous dextrose in an attempt to correct the hypoglycaemia. Phenytoin was administered when further convulsions occurred during these episodes of hypoglycaemia (see later). The first sustained rise of plasma glucose concentration to $3 \mathrm{mmol} / \mathrm{l}$ was observed after treatment with a $200 \mu \mathrm{g} / \mathrm{kg}$ bolus of intravenous glucagon. One further episode of hypoglycaemia occurred 48 hours later and the baby was established on full oral feeds by day 10 . Plasma glucagon and insulin concentrations were measured during the study.

Cases 5 and 6. Case 5 was the sister of case 3 and was born one year later. In view of the history of her brother, her blood glucose concentration was measured after birth and found to be $0 \mathrm{mmol} / \mathrm{l}$. She was treated with glucagon and made an uneventful recovery.

Case 6 had a clinical history that was similar to cases 1-4. Plasma insulin and glucagon concentrations were measured during treatment with glucagon.

\section{Methods}

All blood samples were collected from heparinised intravenous cannulae and placed on ice in prechilled fluoride tubes for the glucose and insulin assays. Tubes containing edetic acid and $1000 \mathrm{KIU}$ of aprotinin were used for the glucagon assays. The plasma was separated by centrifugation at $4^{\circ} \mathrm{C}$ and frozen within 20 minutes of collection. The samples were thawed only once and kept on ice during the assays. The total volume of plasma required for the 
insulin, glucagon, and tracer/total glucose assays was $250 \mu \mathrm{l}$.

Total glucose concentrations in the plasma, tracer infusate, and dextrose solutions were measured using a commercially available glucose oxidase spectrophotometric assay (Boehringer-Mannheim) and an Analox LM3 analyser (Analox Instruments). The calibration curve for the glucose oxidase assay was constructed using gravimetric standards $(0 \cdot 5-$ $0.9 \mathrm{mmol} / \mathrm{l})$. A regression analysis showed that differences of $0.4 \mathrm{mmol} / \mathrm{l}$ could be measured with a standard error of $0.1 \mathrm{mmol} / \mathrm{l}$. The accuracy of the Analox Analyser was improved by modifying the output to display the glucose concentration to the second decimal place and recalibrating the machine every 10 samples. As an additional check recalibration was carried out if calibration standards (which were inserted every fifth sample) differed by more than $2 \%$ from the expected value. All samples were measured at least in duplicate and the standards used were of appropriate composition for the sample being assayed-that is, plasma based standards for plasma samples.

The turnover of glucose was measured using 6,6-dideuteroglucose, which is a non-recycling glucose molecule that is labelled with a stable isotope of hydrogen. It was administered intravenously with a prime dose $(30 \mathrm{mg} / \mathrm{kg})$ followed by a continuous infusion at a rate that was small compared with the dextrose administration rate $(0.94 \mu \mathrm{mol} / \mathrm{kg} / \mathrm{min}$ and $55-83 \mu \mathrm{mol} / \mathrm{kg} / \mathrm{min}$, respectively).

A two hour distribution period was allowed after the priming dose to ensure a steady rate of tracer enrichment within the total glucose pool before any samples were taken. The enrichment of tracer in the plasma samples and the labelled infusates were measured using a Finnigan MAT 4000 combined gas chromatograph and mass spectrometer. The $\alpha$-Dglucofuranose cyclic 1,2:3,5 bis(butylboronate)-6acetate derivative was prepared for gas chromatography ${ }^{2}$ and the $[\mathrm{M}-57]^{+}$ions $(\mathrm{m} / \mathrm{Z} 297$ and 299 for the unlabelled and labelled derivatives, respectively) were analysed in selected ion monitoring mode on the mass spectrometer using electron impact at $70 \mathrm{eV}$.

Glucagon concentration was measured using a radioimmunoassay (Novo Research Institute) with ${ }^{125}$ I labelled pork glucagon and a rabbit anti-pork glucagon serum K5563. This antibody is specific for pancreatic glucagon. The results for the plasma glucagon concentrations that were at the lower end of the range of our assay are expressed as $<60 \mathrm{ng} / \mathrm{l}$ or $<20 \mathrm{ng} / \mathrm{l}$ (depending on the volume of plasma available). Only concentrations above these limits could be reliably distinguished from zero.

Insulin concentration was determined by a double antibody radioimmunoassay ${ }^{3}$ with a coefficient variation of $6.5 \%$. The assay was modified by doubling the number of points on the standard curve and increasing the incubation time to improve its accuracy at low concentrations of insulin. This assay could reliably distinguish insulin concentrations of $>1.2 \mu \mathrm{U} / \mathrm{ml}$ from zero. All samples for insulin and glucagon were assayed at least in duplicate.

\section{Calculations of glucose turnover rates.}

\section{Case 1}

The calculations are based on standard tracer kinetics. The rate of glucose entering the total glucose pool has two inputs, the dextrose infusion rate ( $\mathrm{Ri}$ ) and an unknown endogenous hepatic production rate $(\mathrm{Rh})$. The tracer is infused at a known rate $\left(\mathrm{Rt}^{*}\right)$. In the steady state the pool size is constant and the total glucose appearance rate $(\mathrm{Ra})$ is equal to the sum of $\mathrm{Ri}$ and $\mathrm{Rh}$. $\mathrm{Ra}$ is also equal to the disappearance rate of glucose ( $\mathrm{Rd})$.

$$
\begin{aligned}
\mathrm{Ri}+\mathrm{Rh} & =\mathrm{Ra} \\
& =\mathrm{Rd}
\end{aligned}
$$

Ra can be calculated from the steady state tracer equation ${ }^{4}$ shown below.

$$
\mathrm{RA}=\left[\frac{\text { Tracer infusate enrichment }}{\text { Plasma enrichment }}-1\right] \mathrm{Rt}^{*}
$$

As $\mathrm{Ri}$ is known $\mathrm{Rh}$ can be calculated from equation 1 .

This equation was used in experiments both before and after administration of diazoxide in case 1 .

\section{Cases 2 and 3}

This steady state tracer equation could not be used to calculate $\mathrm{Ra}$ in these babies because the plasma glucose concentrations were not constant. Steele's

\begin{tabular}{|c|c|c|c|c|}
\hline & $\begin{array}{l}\text { Mean (SEM) plasma } \\
\text { glucose concentration } \\
(\mathrm{mmol} / \mathrm{l})\end{array}$ & $\begin{array}{l}\text { Mean }(S E M) \text { plasma } \\
\text { insulin concentration } \\
(\mu U / m l)\end{array}$ & $\begin{array}{l}\text { Infusion rate of } \\
\text { intravenous dextrose } \\
(\mu \mathrm{mol} / \mathrm{kg} / \mathrm{min})\end{array}$ & $\begin{array}{l}\text { Hepatic glucose } \\
\text { production } \\
(\mu \mathrm{mol} / \mathrm{kg} / \mathrm{min})\end{array}$ \\
\hline Experiment 1 (before diazoxide) & $2.63(0.01) \quad(n=14)$ & $4 \cdot 2(0 \cdot 2) \quad(n=5)$ & 59 & 13 \\
\hline Experiment 2 (diazoxide study) & $6.41(0.02)(n=9)$ & $<1 \cdot 2$ & $7 \cdot 6$ & 29 \\
\hline
\end{tabular}
method for measuring glucose turnover in the non-

Table 2 Results in case 1 of glucose turnover studies before and after treatment with diazoxide 
steady state was employed instead. ${ }^{5}$ This method is a one compartment approximation of the total glucose pool and requires prior knowledge of the 'pool fraction', a multiplier that is applied to the true volume of distribution of glucose and takes a value between 0 and 1 . Animal experiments indicate that the optimum value of the pool fraction is $0 \cdot 65 .^{6}$ The computations were performed on a DEC20 mainframe computer using an interactive tracer analysis programme specifically designed by one of us for this task. ${ }^{7}$ Equation 1 was then used again to calculate $\mathrm{Rh}$.

The observed data were smoothed by least squares using low order spline functions. ${ }^{7}$ The degree of smoothing was such that the average departure of the fitted curve from the observed points was less than the estimated accuracy of the observations themselves.

\section{Results}

Case 1. (Table 2.) Before treatment with diazoxide the hepatic glucose production rate was $13 \mu \mathrm{mol} / \mathrm{kg} /$ minute; the normal range for fasting term neonates is $27-44 \mu \mathrm{mol} / \mathrm{kg} /$ minute. ${ }^{8}$ This had increased to 28 $\mu \mathrm{mol} / \mathrm{kg} /$ minute after treatment. The mean (SEM) insulin concentrations before and after treatment were $4 \cdot 2(0 \cdot 2) \mu \mathrm{U} / \mathrm{ml}(\mathrm{n}=5)$ and less than $1.2 \mu \mathrm{U} / \mathrm{ml}$, respectively. The highest observed insulin concentration was $11.8 \mu \mathrm{U} / \mathrm{ml}$, and this sample was taken at a time when the baby was receiving intravenous dextrose and the glucose concentration was $2 \cdot 4$ $\mathrm{mmol} / \mathrm{l}$.

\section{Cases 2 and 3}

The plasma insulin concentrations were only 10 $\mu \mathrm{U} / \mathrm{ml}$ in both babies when the dextrose infusion rate was transiently decreased in an attempt to reduce the plasma glucose concentration to below 2 $\mathrm{mmol} / \mathrm{l}$. Figures 1 and 2 show that the rate of hepatic glucose production was negligible in both these patients before treatment with intravenous glucagon. This is clearly shown by nearly identical results for total glucose appearance rate as measured by tracer $(\mathrm{Ri}+\mathrm{Rh})$ and the known dextrose infusion rate $(\mathrm{Ri}) . \mathrm{Ri}$ is indicated by the dotted line in Figures 1(c) and 2(c) and the rise in hepatic glucose production after glucagon is shown by the divergence of total glucose appearance rate (solid line) and the constant dextrose infusion rate.

This improvement in HGPR was sustained for the rest of the natural history in case 2 as is clearly shown by the ranges of blood glucose in the hours before and after administration of glucagon $(0 \cdot 2-4 \cdot 3$ $\mathrm{mmol} / \mathrm{l}$ and $4 \cdot 2-9 \cdot 8 \mathrm{mmcl} / \mathrm{l}$, respectively). Case 3
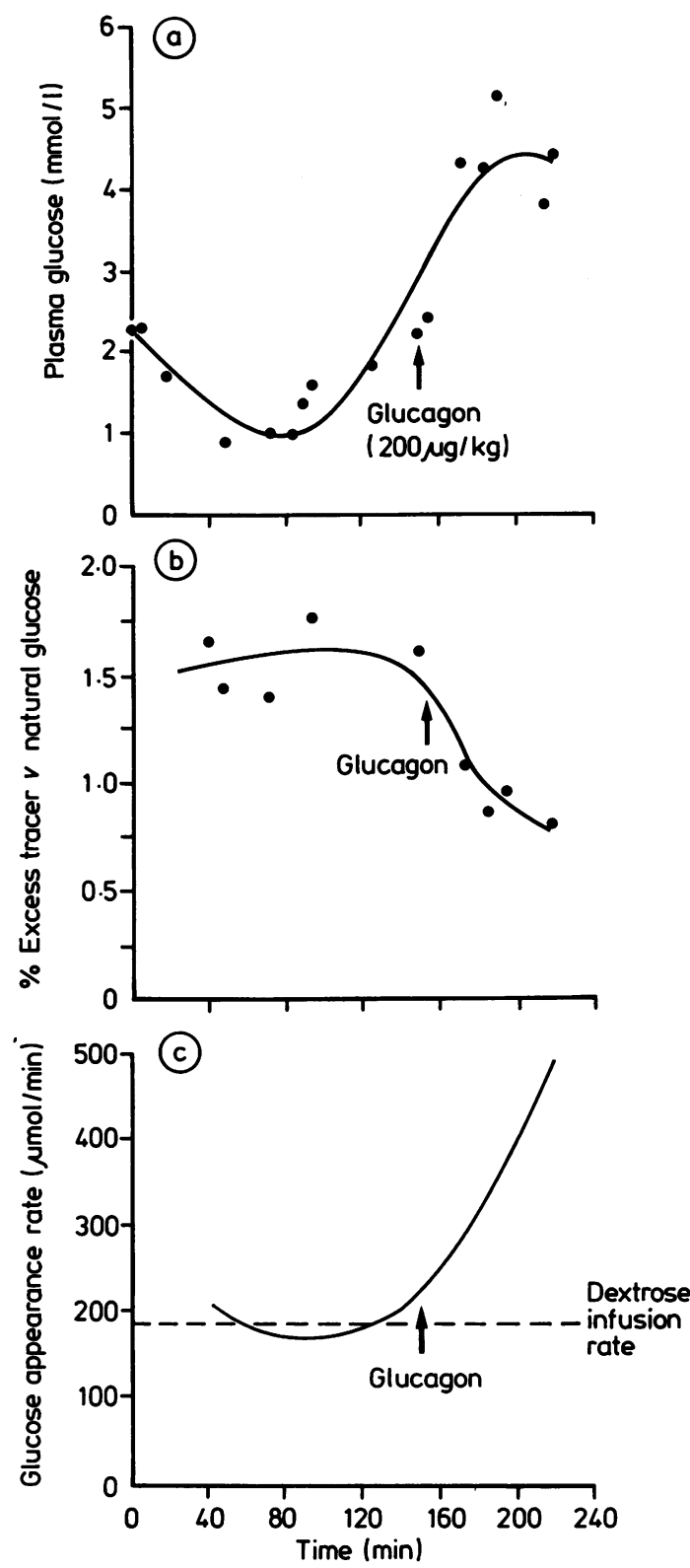

Fig. 1 Results of non-steady state glucose turnover experiments in case 2. (a) Effect of glucagon on plasma glucose; (b) effect of glucagon on tracer enrichment; and (c) change in total glucose appearance rate ( $R a-$ see text) with glucagon. The dotted lines in (c) represent the rate of intravenous dextrose administration. The difference between the dotted and solid lines is the net hepatic glucose production rate. Each arrow marks the time at which glucagon bolus was administered intravenously. The plasma insulin concentrations were all $<6 \mu \mathrm{U} / \mathrm{ml}$ in the first 100 minutes and $<12 \mu \mathrm{U} / \mathrm{ml}$ after treatment. 

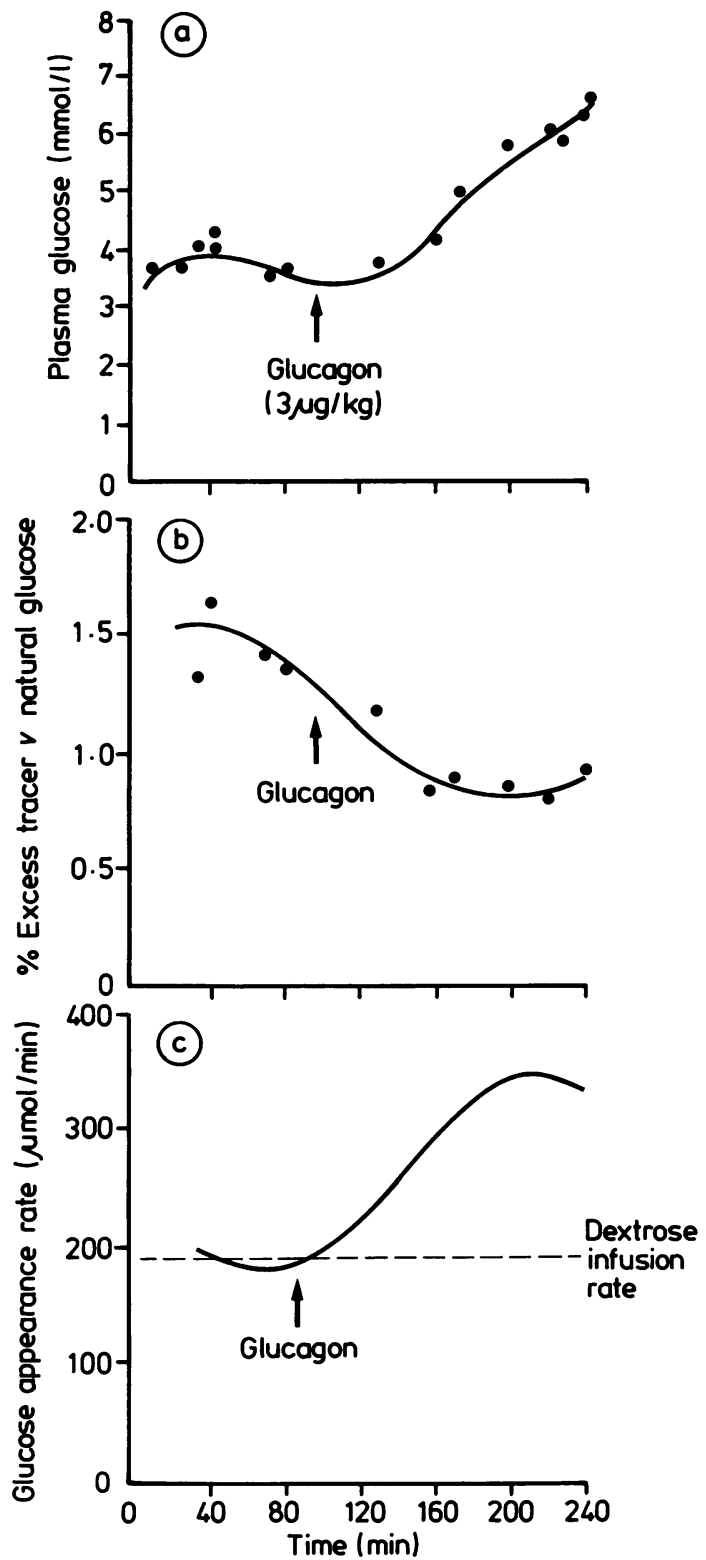

Fig. 2 Results of non-steady state glucose turnover experiments in case 3 (see legend to Fig. 1 for details).

showed a similar improvement for nine hours after receiving a smaller, more 'physiological' dose of glucagon $(1.5 \%$ of that given to case 2$)$. The ranges for the pretreatment and post-treatment insulin concentrations were 4-6 and $10-12 \mu \mathrm{U} / \mathrm{ml}$, respectively, for both babies. These 'normal' concentrations before treatment were observed at a time when the hepatic glucose production rate was zero. The plasma glucagon concentration in case 3 before treatment with glucagon was $<60 \mathrm{ng} / \mathrm{l}$.

\section{Discussion}

Previous workers have measured the hepatic glucose production rate in clinically stable neonates who did not have severe hypoglycaemia at term. ${ }^{8-10}$ These infants either had normal intravenous dextrose requirements or were able to tolerate short periods of fasting. Kalhan showed a reduction in hepatic glucose production rate in infants of mothers with gestational diabetes,${ }^{10}$ but this complication was not present during pregnancy in any of our babies.

The hepatic glucose production rate was low before treatment in all the babies studied here. This was accompanied by a raised glucose disappearance rate $(\mathrm{Ri}+\mathrm{Rh})$, and yet in cases 1,2 , and 3 the insulin concentrations were never in the accepted range for hyperinsulinism. ${ }^{11} 12$

The glucagon concentrations were lower than expected for term neonates ${ }^{13}$ and may have facilitated excessive insulin activity, despite a low absolute concentration. It is well recognised that it is the molar ratio of glucagon/insulin that is of vital importance in determining the balance of production and consumption of glucose. ${ }^{14}$ This argument is also supported by the restoration of hepatic glucose production rate associated with further suppression of a 'normal' insulin concentration using diazoxide in case 1.

The response to a single bolus of glucagon is also interesting because of its sustained effect. Case 2 required only a single bolus $(200 \mu \mathrm{g} / \mathrm{kg})$ and case 3 , who had a much lower dose $(3 \mu \mathrm{g} / \mathrm{kg})$, maintained his plasma glucose concentration in the normal range for nine hours. This persistent action may perhaps be explained by the observation that phosphoenolpyruvate carboxykinase (PEPCK) activity, which is essential for gluconeogenesis, is strongly induced by a high glucagon/insulin molar ratio. ${ }^{15}$ This ratio is low during fetal life, and postnatal induction of PEPCK occurs in response to the surge of glucagon secretion, which normally occurs after birth. ${ }^{15}$

A previous study showed that the fall in blood glucose concentration shortly after birth was associated with a rise in plasma gluconeogenic amino acids, but no hormone measurements were made at this time. ${ }^{16}$ It was suggested that part of the fall in blood glucose was due to a delay in the maturation of gluconeogenic enzymes. These infants were very small for dates, with a mean birth weight of only $2300 \mathrm{~g}$ at term, which is much lower than our study group. 
One of the arguments for not using treatment with glucagon has been that it provokes insulin release, but this is a transient effect ${ }^{17}$ and may not be important after treatment in the patient because the molar ratio of the two hormones still favours net glucose release from the liver. This is clearly shown in table 3 where the high plasma glucagon concentration of $>2000 \mathrm{ng} / \mathrm{l}$ was still present three hours after a bolus of glucagon. It is also interesting to note that case 5 , the sister of case 3 was born one year later, and also had severe hypoglycaemia at term that responded to treatment with glucagon. The plasma glucagon concentration was $<20 \mathrm{ng} / \mathrm{l}$ and the insulin concentration was $4 \mu \mathrm{U} / \mathrm{ml}$ at a blood glucose concentration of $0 \mathrm{mmol} / \mathrm{l}$. Both siblings tolerated prolonged fasting a few days after treatment but some familial cause for the lack of glucagon secretion cannot be ruled out in these cases. Vidnes described a case of permanent plasma glucagon deficiency that also had a familial basis, ${ }^{18}$ but this child came from a consanguineous marriage, which was not the case in our babies.

Case 4 had already received several boluses of dextrose in the hours before the plasma sample was collected for insulin measurement. The high insulin concentration found in this baby may have been stimulated by the sudden rise in plasma glucose concentration after each bolus. The dextrose infusion rate required to maintain euglycaemia was not excessive $(38.8 \mu \mathrm{mol} / \mathrm{kg} / \mathrm{min})$, which is particularly interesting because the baby was on phenytoin at this time to treat the convulsions that had occurred soon after birth. It is not generally realised that this drug suppresses insulin release from the beta cell of the pancreas. ${ }^{19}{ }^{20}$ When the phenytoin was withdrawn the dextrose requirements increased to 83 $\mu \mathrm{mol} / \mathrm{kg} / \mathrm{min}$. This has considerable clinical relevance because a high intravenous dextrose requirement is one of the hallmarks of excessive insulin activity. The use of phenytoin could easily mask this sign and confuse the clinical picture because hypoglycaemia might then recur as the suppressive effect on the beta cell is lost. This seems to be the most likely explanation for the second episode of hypoglycaemia in case 4 (table 3 ).

This second episode was associated with a recurrence of the low glucagon concentration $(60-80 \mathrm{ng} / \mathrm{l})$ and an inappropriately high insulin concentration $(14 \mu \mathrm{U} / \mathrm{ml})$ for the prevailing blood glucose concentration of $1.6 \mathrm{mmol} / \mathrm{l}$. On day 12 the baby was fasted for four hours and no hypoglycaemia occurred. The plasma glucagon concentration was then in the normal range for term neonates.

We have shown that a reduced hepatic glucose production rate can occur even when the classical diagnostic criteria for the hyperinsulinism are not present. The absolute concentration of insulin during hypoglycaemia is often used as a marker for hyperinsulinism, and it is important to realise that when high insulin concentrations are not present excessive insulin activity can still occur because of glucagon deficiency.

Abnormalities in the mechanisms that control the molar ratio of insulin to glucagon may be of greater importance than 'hyperinsulinism' per se in the pathogenesis of hypoglycaemia in those term neonates who require excessive quantities of intravenous dextrose.

The high plasma glucagon concentration after an intravenous bolus initially releases stored glucose (from hepatic glycogen) but may also have a longer term action on the induction of PEPCK, which is a key enzyme in gluconeogenesis.

Intravenous glucagon boluses may be a better initial treatment for unexpected hypoglycaemia in the term neonate because they avoid the rebound hypoglycaemia associated with boluses of dextrose or sudden termination of dextrose infusion.

\section{Addendum}

Since the acceptance of this paper we have studied two infants in greater detail. Both infants had similar histories to our original cases and had

Table 3 Results in case 4 of plasma glucagon and insulin concentrations during treatment with glucagon

\begin{tabular}{|c|c|c|c|}
\hline & $\begin{array}{l}\text { Insulin } \\
(\mu U / m l)\end{array}$ & $\begin{array}{l}\text { Glucagon } \\
(n g / l)\end{array}$ & $\begin{array}{l}\text { Mean (range) glucose } \\
\text { (mmolll) }\end{array}$ \\
\hline \multicolumn{4}{|l|}{ Day 6} \\
\hline Before glucagon & 45 & $<60$ & $3 \cdot 28(3 \cdot 1-3 \cdot 46) \quad(n=5)$ \\
\hline One hour after glucagon & $47 \cdot 5$ & $>2000$ & $5 \cdot 23(3 \cdot 31-7 \cdot 56)(n=9)$ \\
\hline Three hours after glucagon & $4 \cdot 6$ & $>2000$ & 3.0 (Single sample) \\
\hline \multicolumn{4}{|l|}{ Day 8} \\
\hline During second episode of hypoglycaemia & 14 & $60-80$ & 1.6 (Single sample after three hour fast) \\
\hline \multicolumn{4}{|l|}{ Day 12} \\
\hline After recovery & 13 & 190 & 3.86 (Single sample after four hour fast) \\
\hline
\end{tabular}


undetectable plasma glucagon concentrations $(<20$ $\mathrm{ng} / \mathrm{l})$ when the HGPR was zero. The plasma insulin concentrations were $<6$ and $14 \mu \mathrm{U} / \mathrm{ml}$, respectively. A $200 \mu \mathrm{g} / \mathrm{kg}$ bolus of intravenous glucagon produced a sustained rise in HGPR, and plasma glucagon concentrations were within the range $180-240 \mathrm{ng} / \mathrm{l}$ at 48 hours when clinical recovery had taken place. We see about two cases per year in our hospital, which suggests an incidence of the order of 1 per 1500 live births. We believe that early recognition of transient glucagon deficiency and prompt treatment with intravenous glucagon is of benefit in these infants.

We are indebted to the following for their help: Celia Shore RSCN (Research Nurse); the junior medical staff and nurses on SCBU; and Joan Gandy for help in setting up the hormone assays. We also thank Drs Liberman. Valman. and Thomas for allowing us to study their infants.

\section{References}

1 Otaga ES. Carbohydrate metabolism in the fetus and neonate and altered neonatal glucoregulation. Pediatr Clin North Am 1986;33:25-45.

2 White E, Welch MJ, Sun T, et al. The accurate determination of serum glucose by isotope dilution mass spectrometry-two methods. Biomed Mass Spectrom 1982;9:395-405.

${ }^{3}$ Midgley AF, Rebor RW, Niswender GD. Radioimmunoassays employing double antibody techniques. Acta Endocrinol (Suppll Copenh) 1969;142:247-54.

4 Wootton R, Ford GC, Cheng KN, et al. Calculation of turnover rates in stable isotope studies. Phys Med Biol 1985;30:1143-9.

${ }^{5}$ Steele R. Influence of glucose loading and of injected insulin on hepatic glucose output. Am N Y Acad Sci 1959;82:420-30.

${ }^{6}$ Radziuk J, Norwich KH, Vranic M. Experimental validation of measurements of glucose turnover in non steady state. $A m J$ Physiol 1978;234:84-93.

${ }^{7}$ Wootton R, Ashley K. ITA a portable program for the interactive analysis of data from tracer experiments. Comput Biol Med 1985;15:247-57.

${ }^{8}$ Bier DM, Leake R, Haymond MW, et al. Measurement of true glucose production rates in infancy and childhood with 6,6dideuteroglucose. Diabetes 1977;26:1016-23.

${ }^{9}$ Cowett RM, Oh W, Schwartz R. Persistent glucose production during glucose infusion in the neonate. $J$ Clin Invest 1983;71:467-75

10 Kalhan SC, Savin SM, Adam PAJ. Attenuated glucose production rate in newborn infants' of insulin dependent diabetic mothers. N Engl J Med 1977;296:375-6.

"Collins JE, Leonard JV. Hyperinsulinism in asphyxiated and small-for-dates infants with hypoglycaemia. Lancet 1984;ii: 311-3.

${ }^{12}$ Stanley CA, Baker L. Hyperinsulinism in infancy: diagnosis by demonstration of abnormal response to fasting hypoglycaemia. Pediatrics 1976;57:702-11.

13 Johnston DI, Bloom SR. Plasma glucagon levels in the term human infant and effect of hypoxia. Arch Dis Child 1973;48:451-4

14 Ktorza A, Girard JR, Kinebanyan MF, et al. Hypoglycaemia induced by glucose infusion in unrestrained pregnant rat during the last 3 days of gestation: metabolic and hormonal changes in the mother and fetus. Diabetologia 1981;21:569-74.

15 Girard JR, Caquet D, Bal D, et al. Control of rat liver phosphorylase glucose 6 phosphatase and phosphoenolpyruvate carboxykinase activities by insulin and glucagon during the perinatal period. Enzyme 1973;15:272-85.

16 Haymond MW, Karl IE, Pagliara AS. Increased gluconeogenic substrates in small for gestational age infant. $N$ Engl $J$ Med 1974:291:322-8.

${ }^{17}$ Milner RDG, Wright AD. Plasma glucose, non-esterified fatty acid, insulin and growth hormone response to glucagon in the newborn. Clin Sci 1967;32:249-55.

18 Vidnes J, Oyasaeter S. Glucagon deficiency causing severe neonatal hypoglycaemia in a patient with normal insulin secretion. Pediatr Res 1977;11:943-9.

19 Cohen MS, Bower RH, Fidler SM, et al. Inhibition of insulin release by diphenylhydantoin and diazoxide in a patient with benign insulinoma. Lancet 1973;i:40.

20) Malherbe C, Burrill KC, Levin SR, et al. Effect of diphenylhydantoin on insulin secretion in man. $N$ Engl $J$ Med 1972;286:339-42.

Correspondence to $\mathrm{Dr}$ A Mehta, Clinical Research Centre, Perinatal and Child Health, Watford Road, Harrow, Middlesex HA1 3UJ.

Received 15 December 1986 